\title{
The Effect of Kangaroo Mother Care on Increasing the Body Weight in Infants with Low Birth Weight: A Meta-Analysis
}

\author{
Anggun Fitri Handayani'), Yulia Lanti Retno Dewi²), \\ Eti Poncorini Pamungkasari²) \\ ${ }^{1)}$ Masters Program in Public Health, Universitas Sebelas Maret \\ 2)Faculty of Medicine, Universitas Sebelas Maret
}

\section{ABSTRACT}

Background: Low Birth Weight (LBW) is a condition of babies born weighing <2,500 grams regardless of gestational age. Stabilization of the general condition is an important thing to do during the treatment period, there are several treatments for LBW babies, namely standard care with an incubator, monitoring nutritional intake and doing kangaroo mother care. This study aims to analyze the effect of kangaroo mother care on weight gain in LBW infants, with a meta-analysis of primary studies conducted by previous authors.

Subjects and Method: This study is a systematic review and meta-analysis with the following PICO, population: infants with low birth weight. Intervention: Kangaroo Mother Care. Comparison: Conventional Method Care. Outcome: weight gain. The articles used in this study were obtained from three databases, namely Google Scholar, Pubmed, Science Direct and Springerlink. Keywords to search for articles "kangaroo mother care" AND "weight gain" OR "growth" AND "neonatal outcome" AND "low baby weight infants" OR "skin to skin contact" OR "kangaroo care" OR "kangaroo method" AND "Randomized Controlled Trial" OR "RCT". The articles included are full-text English and Indonesian with a study design of a Randomized Controlled Trial from 2007 to 2020 and reporting on the Mean and SD in multivariate analysis. The selection of articles is done by using PRISMA flow diagram. Articles were analyzed using the Review Manager 5.3 application.

Results: A total of 11 randomized controlled trials from India, Nepal, Pakistan, Bangladesh, Malaysia, Kenya, and Egypt were selected for a systematic review and meta-analysis. The data collected showed that kangaroo mother care increased the weight of LBW infants and was statistically significant $(\mathrm{SMD}=1.05 ; 95 \% \mathrm{CI}=0.56$ to $1.54 ; \mathrm{p}<0.001)$.

Conclusion: Kangaroo mother care increases weight in LBW babies.

Keywords: kangaroo mother care, body weight, LBW, meta-analysis

Correspondence:

Anggun Fitri Handayani. Masters Program in Public Health, Universitas Sebelas Maret, Jl. Ir. Sutami 36A, Surakarta 57126, Central Java. Email: handayanianggun22@gmail.com. Mobile: +6281225095742.

\section{Cite this as:}

Handayani AF, Dewi YRL, Pamungkasari EP (2021). The Effect of Kangaroo Mother Care on Increasing the Body Weight in Infants with Low Birth Weight: A Meta-Analysis. J Matern Child Health. J Matern Child Health. 06(06): 707-718. https://doi.org/10.26911/thejmch.2021.06.06.09.

(c) (i) (2) Journal of Maternal and Child Health is licensed under a Creative Commons Journal of Maternal and Child Health is licensed under a Creative Con
Attribution-NonCommercial-ShareAlike 4.o International License.

\section{BACKGROUND}

Birth weight is defined as the weight of a baby who is weighed within the first 1 (one) hour after birth, measurements are made at the facility (hospital, public health center, and polindes), whereas if the baby is born at home, the measurement is taken (DK et al., 2011).

The causes of LBW babies are generally multi-factorial, however, the most 
common cause of LBW babies is premature birth. Other maternal factors are age, parity, and others. Placental factors such as vascular disease, multiple pregnancies, and fetal factors are also the causes of low birth weight (Hasegawa et al., 2011).

According to WHO (2014b) there are 5 million neonatal deaths every year with a mortality rate (death in the first 28 days of life) is 34 per 1 ,ooo live births, and $98 \%$ of these deaths come from developing countries. The incidence of low birth weight infants (LBW) in developing countries is $16.5 \%$, twice as large as $7 \%$ in developed countries. Statistically, $90 \%$ of the incidence of LBW is found in developing countries and the mortality rate is 35 times higher than in infants whose body weight is more than 2,500 grams.

The infant mortality rate (IMR) in Indonesia is considered the highest when compared to other ASEAN countries. From 2020 to August there were 74 cases of neonatal deaths, AKN 6.23/1,000 live births and 116 post-neonatal deaths, IMR 9.78/1,000 live births (BPS, 2020). This data has not yet reached the target of the WHO program, namely the Sustainable Development Goals (SDGs) which targets an IMR of at least 12 per 1,00o live births. One of the main causes of infant mortality is low birth weight (LBW).

The use of the KMC method in LBW babies has a positive effect on the duration of breastfeeding and the baby's temperature is within the normal range. Babies who are given $\mathrm{KMC}$ have a body temperature within normal limits and have regular heart and breathing rhythms, sleep deeper, cry less, have a lower incidence of infection, more weight gain, and early discharge (Rohani et al, 2017; Bera et al, 2014).

Based on this background, a comprehensive study is needed from various primary studies on the effect of the KMC method on weight gain. This study aims to analyze the effect of kangaroo mother care on weight gain in LBW infants.

\section{SUBJECTS AND METHOD}

\section{Study Design}

This research is a systematic review and meta-analysis. The articles used in this study were obtained from several databases, namely Google Scholar, Pubmed, and Science Direct and Springerlink between 2007 and 2020. The selection of articles was carried out using PRISMA flow diagrams. The keywords to search for articles were as follows "kangaroo mother care" AND "weight gain” OR "growth" AND "neonatal outcome" AND "low baby weight infants" OR "skin to skin contact" OR "kangaroo care" OR " kangaroo method" AND "Randomized Controlled Trial" OR "RCT".

\section{Inclusion Criteria}

The inclusion criteria in this research article are: full-text article using a randomized controlled trial study design, research subjects are infants with low birth weight, the relationship size used is Mean and SD, the intervention given is kangaroo mother care, the study outcome is weight gain.

\section{Exclusion Criteria}

Exclusion criteria in this research article are: articles published in languages other than English and Indonesian, articles before 2007, articles are not free access.

\section{Operational Definition of Variable}

The search for articles was carried out by considering the eligibility criteria determined using the PICO model. Population: babies with LBW. Intervention: kangaroo mother care (KMC). Comparison: conventional method care (CMC). Outcome: weight gain.

Kangaroo Mother Care (KMC) is a special care method for low birth weight babies $(<2,500 \mathrm{~g})$ or premature babies ( $<37$ weeks) by making direct contact between the skin of 
the mother or caregiver with the baby's skin. The instrument used is kangaroo mother care SOP. The measurement scale is categorical.

Weight gain was defined as the total weight gain of LBW infants after being given kangaroo mother care (KMC) intervention. The instrument used is a digital baby scale. The measurement scale is continuous.

\section{Instrument Study}

The study was guided by the PRISMA flow diagram and quality assessment using the Critical Appraisal for Randomized Controlled Trial CEBM (Center For EvidenceBased Medicine).

\section{Data Analysis}

The data in the study were analyzed using the Review Manager application (Rev-Man 5.3). Forest plots and funnel plots were used to determine the size of the relationship and heterogeneity of the data. The fixed effect model is used for homogeneous data, while the random effect model is used for heterogeneous data across studies.

\section{RESULTS}

The article search process is carried out through several journal databases including Google Scholar, Pubmed, Science Direct and Springerlink. The review process for related articles can be seen in the PRISMA flow diagram in Figure 1. Research related to the effect of kangaroo mother are on weight gain in LBW infants consisting of 11 articles from the initial search process yielding 1,011 articles, after the deletion process of published articles, 1,011 articles were obtained with 53 of them met the requirements for further fulltext review. A total of 11 articles that met the quality assessment were included in the quantitative synthesis using a meta-analysis.

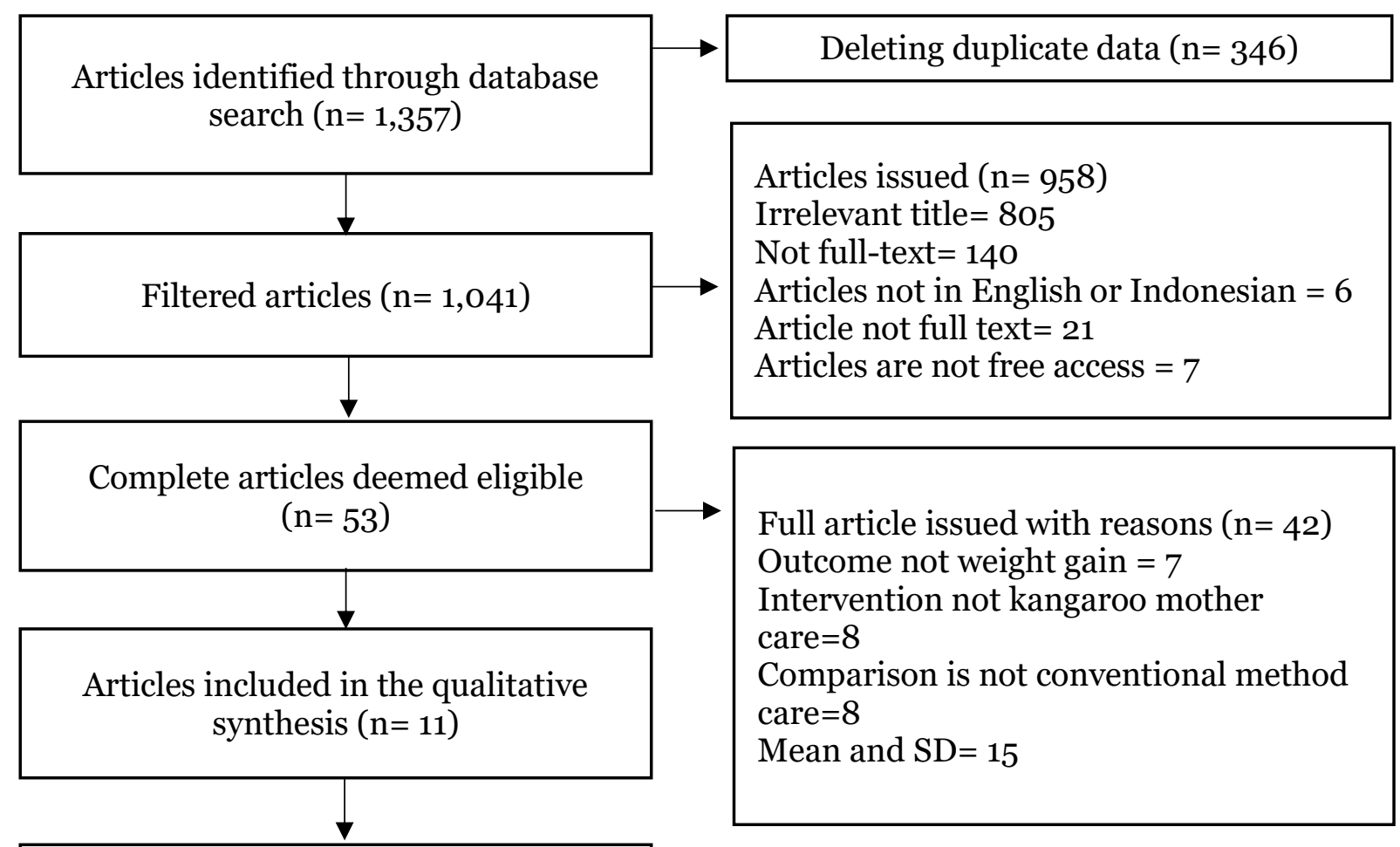

Articles included in the systematic review and meta-analysis $(n=11)$

Figure 1. PRISMA flow diagram 
It can be seen in Figure 2 that the research articles come from 2 continents, namely Asia (India, Nepal, Pakistan, Bangladesh, and Malaysia), Africa (Kenya, and Egypt). Table 1. Researchers conducted an assessment of the quality of the study. Table 2. shows that 11 articles from a randomized controlled trial (RCT) provide evidence of the effect of kanga-roo mother care on weight gain in LBW infants.

Based on the results of the forest plot study, a randomized controlled trial showed that kangaroo mother care affected weight gain in LBW infants by 1.05 times compared to conventional method care $(\mathrm{SMD}=1.05$ :
$95 \% \mathrm{CI}=0.56$ to $1.54 ; \mathrm{p}<0.001)$. and the results were statistically significant. The heterogeneity of the research data shows I2 = 94\% so that the distribution of the data is declared heterogeneous (random effect model).

The funnel plot results show a publication bias with an overestimated effect which is indicated by an asymmetric distribution between the right and left plots. There are three plots on the left, six plots on the right, and one plot touching the vertical line. The plot on the left side of the graph has a standard error (SE) between 0 and 0.4. The plot on the right side of the graph has a standard error (SE) between 0.2 and 0.4 .

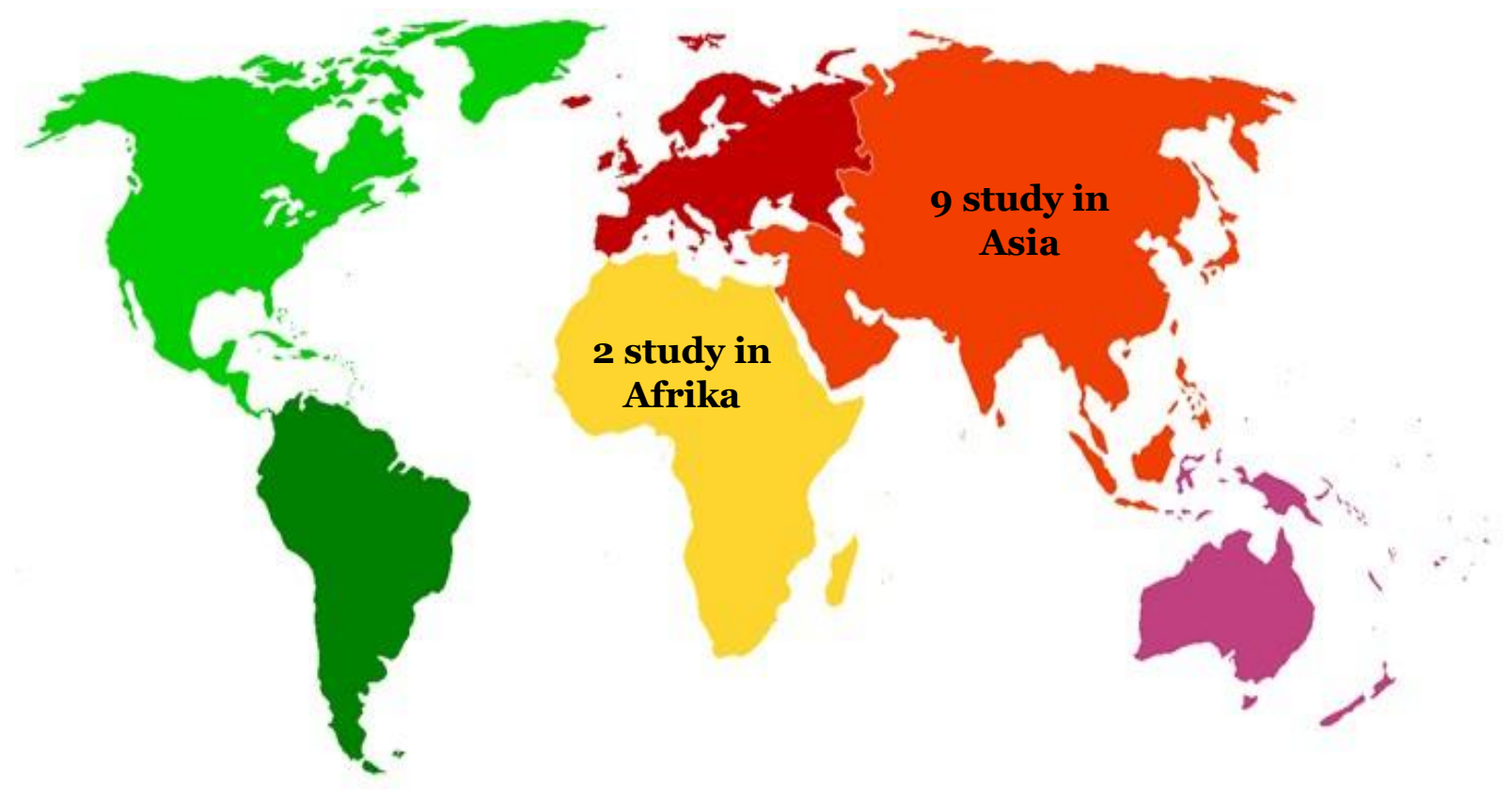

Figure 2. Map of the study area 
Table 1. Assessment of study quality published by the Center for Evidence-Based Medicine (CEBM)

\begin{tabular}{|c|c|c|c|c|c|c|}
\hline \multirow[b]{2}{*}{ No } & \multirow[b]{2}{*}{ Questions } & \multicolumn{5}{|c|}{ Publication (Author and Year) } \\
\hline & & $\begin{array}{c}\text { Boo et } \\
\text { al. } \\
2007\end{array}$ & $\begin{array}{c}\text { Gathwala } \\
\text { et al., } \\
\text { 2010 }\end{array}$ & $\begin{array}{c}\text { Ghavane } \\
\text { et al., } \\
2012 \\
\end{array}$ & $\begin{array}{c}\text { Mwendwa } \\
\text { et al., } \\
2012 \\
\end{array}$ & $\begin{array}{l}\text { Samra et } \\
\text { al., } 2013\end{array}$ \\
\hline 1 & Does this study address a clear research focus? & 1 & 1 & 1 & 1 & 1 \\
\hline 2 & $\begin{array}{l}\text { Is the Randomized Controlled Trial research method appropriate to } \\
\text { answer the research question? }\end{array}$ & 1 & 1 & 1 & 1 & 1 \\
\hline 3 & $\begin{array}{l}\text { Are there enough subjects in the study to establish that the findings were } \\
\text { not coincidental? }\end{array}$ & 1 & 1 & 1 & 1 & 1 \\
\hline 4 & $\begin{array}{l}\text { Were the subjects randomly divided into the experimental and control } \\
\text { groups? If not, can this be biased? }\end{array}$ & 1 & 1 & 1 & 1 & 1 \\
\hline 5 & Does the study use inclusion/exclusion criteria? & 1 & 1 & 1 & 1 & 1 \\
\hline 6 & Were the two groups comparable at the start of the study? & 1 & 1 & o & 1 & 1 \\
\hline 7 & Were objective and unbiased outcome criteria used? & 1 & 1 & 1 & 1 & 1 \\
\hline 8 & $\begin{array}{l}\text { Is the measurement method used objective and valid to measure the } \\
\text { results? If not, is there any blinding in the study? }\end{array}$ & 1 & 1 & 1 & $\mathrm{O}$ & 1 \\
\hline 9 & Is effect size practically relevant? & 1 & 1 & 1 & 1 & 1 \\
\hline 10 & Is the estimated effect correct? Is there a confidence level interval? & 1 & o & o & 1 & 1 \\
\hline 11 & $\begin{array}{l}\text { Are there any confounding factors that have not been taken into } \\
\text { account? }\end{array}$ & $\mathrm{O}$ & 1 & 0 & 1 & 1 \\
\hline 12 & Can the results be applied to your research? & 1 & 1 & 1 & 1 & 1 \\
\hline & Total of Score & $\mathbf{1 1}$ & $\mathbf{1 1}$ & 9 & $\mathbf{1 1}$ & 12 \\
\hline
\end{tabular}

\section{Note:}

1: Yes; o: No 


\begin{tabular}{|c|c|c|c|c|c|c|c|}
\hline \multirow[b]{2}{*}{ No } & \multirow[b]{2}{*}{ Indicator } & \multicolumn{6}{|c|}{ Publication (Author and Year) } \\
\hline & & $\begin{array}{c}\text { Acharya et } \\
\text { al., } 2014\end{array}$ & $\begin{array}{c}\text { Sharma et } \\
\text { al., } 2016\end{array}$ & $\begin{array}{l}\text { Rahman et } \\
\text { al., } 2017\end{array}$ & $\begin{array}{l}\text { Rehman et } \\
\text { al., } 2020\end{array}$ & $\begin{array}{c}\text { Azad et } \\
\text { al., 2020 }\end{array}$ & $\begin{array}{l}\text { Jahan et } \\
\text { al., 2020 }\end{array}$ \\
\hline 1 & Does this study address a clear research focus? & 1 & 1 & 1 & 1 & 1 & 1 \\
\hline 2 & $\begin{array}{l}\text { Is the Randomized Controlled Trial research method } \\
\text { appropriate to answer the research question? }\end{array}$ & 1 & 1 & 1 & 1 & 1 & 1 \\
\hline 3 & $\begin{array}{l}\text { Are there enough subjects in the study to establish that } \\
\text { the findings were not coincidental? }\end{array}$ & 1 & 1 & 1 & 1 & 1 & 1 \\
\hline 4 & $\begin{array}{l}\text { Were the subjects randomly divided into the experi- } \\
\text { mental and control groups? If not, can this be biased? }\end{array}$ & 1 & 1 & 1 & 1 & 1 & 1 \\
\hline 5 & Does the study use inclusion/exclusion criteria? & 1 & 1 & 1 & 1 & 1 & 1 \\
\hline 6 & $\begin{array}{l}\text { Were the two groups comparable at the start of the } \\
\text { study? }\end{array}$ & 1 & 1 & 1 & 1 & 1 & 1 \\
\hline 7 & $\begin{array}{l}\text { Were objective and unbiased outcome criteria used? } \\
\text { Is the measurement method used objective and valid to }\end{array}$ & 1 & 1 & 1 & 1 & 1 & 1 \\
\hline 8 & $\begin{array}{l}\text { measure the results? If not, is there any blinding in the } \\
\text { study? }\end{array}$ & 1 & 1 & 1 & 1 & 1 & 1 \\
\hline 9 & Is effect size practically relevant? & 1 & 1 & 1 & 1 & 1 & 1 \\
\hline 10 & $\begin{array}{l}\text { Is the estimated effect correct? Is there a confidence } \\
\text { level interval? }\end{array}$ & 1 & $\mathrm{O}$ & 1 & $\mathrm{O}$ & 1 & 1 \\
\hline 11 & $\begin{array}{l}\text { Are there any confounding factors that have not been } \\
\text { taken into account? }\end{array}$ & 1 & 1 & 1 & 1 & 1 & 1 \\
\hline 12 & Can the results be applied to your research? & 1 & 1 & 1 & 1 & 1 & 1 \\
\hline & Total of score & 12 & 11 & 12 & $\mathbf{1 1}$ & 12 & 12 \\
\hline
\end{tabular}

Note:

1: Yes; o: No 
Handayani et al./ Kangaroo Mother Care on Body Weight in Infants with Low Birth Weight

Table 2. Description of the primary studies included in the meta-analysis primary studies

\begin{tabular}{|c|c|c|c|c|c|c|c|c|c|c|c|c|}
\hline \multirow{2}{*}{$\begin{array}{l}\text { Author } \\
\text { (Year) }\end{array}$} & \multirow{2}{*}{ Country } & \multirow{2}{*}{$\begin{array}{l}\text { Study } \\
\text { Design }\end{array}$} & \multicolumn{2}{|c|}{$\begin{array}{l}\text { Total of } \\
\text { Sample }\end{array}$} & \multirow{2}{*}{$\begin{array}{l}\text { Popula- } \\
\text { tion }\end{array}$} & \multirow{2}{*}{$\begin{array}{c}\text { Inter- } \\
\text { vention }\end{array}$} & \multirow{2}{*}{ Comparison } & \multirow{2}{*}{ Outcome } & \multicolumn{2}{|c|}{ Mean } & \multicolumn{2}{|c|}{ SD } \\
\hline & & & KMC & CMC & & & & & KMC & CMC & KMC & CMC \\
\hline $\begin{array}{l}\text { Boo et al., } \\
(2017)\end{array}$ & $\begin{array}{l}\text { Kuala } \\
\text { Lumpur, } \\
\text { Malaysia }\end{array}$ & RCT & 54 & 62 & $\begin{array}{l}\text { LBW } \\
<2000 \text { g }\end{array}$ & $\begin{array}{l}\text { Skin-to- } \\
\text { skin contact } \\
\text { for at least } 5 \\
\text { hours/day }\end{array}$ & $\begin{array}{l}\text { Conventional } \\
\text { Method Care }\end{array}$ & $\begin{array}{l}\text { Weight gain } \\
\text { and head } \\
\text { circum- } \\
\text { ference }\end{array}$ & 28.3 & 27.5 & 11.3 & 9 \\
\hline $\begin{array}{l}\text { Gathwala } \\
\text { et al., } \\
\text { (2010) }\end{array}$ & $\begin{array}{l}\text { Haryana, } \\
\text { India }\end{array}$ & $\mathrm{RCT}$ & 50 & 50 & $\begin{array}{l}\text { LBW } \\
<2500 \text { g }\end{array}$ & $\begin{array}{l}\text { KMC for at } \\
\text { least } 6 \\
\text { hours/day }\end{array}$ & $\begin{array}{l}\text { Conventional } \\
\text { Method Care } \\
\text { and standard } \\
\text { care (using an } \\
\text { incubator }\end{array}$ & Weight gain & 22 & 18.6 & 1.4 & 1.2 \\
\hline $\begin{array}{l}\text { Ghavane } \\
\text { et al., } \\
\text { (2012) }\end{array}$ & India & $\mathrm{RCT}$ & 68 & 68 & $\begin{array}{l}\text { LBW } \\
<2000 \text { g }\end{array}$ & $\begin{array}{l}\text { KMC for at } \\
\text { least } 8 \\
\text { hours/day }\end{array}$ & $\begin{array}{l}\text { Standard or } \\
\text { conventional } \\
\text { care (using an } \\
\text { incubator) and } \\
\text { conventional }\end{array}$ & Weight gain & 23.3 & 22.6 & 8.7 & 7.1 \\
\hline $\begin{array}{l}\text { Mwendwa } \\
\text { et al., } \\
\text { (2012) }\end{array}$ & $\begin{array}{l}\text { Nairobi, } \\
\text { Kenya }\end{array}$ & $\mathrm{RCT}$ & 85 & 81 & $\begin{array}{l}\text { LBW } \\
<2000 \text { g }\end{array}$ & $\begin{array}{l}\text { KMC for at } \\
\text { least } 8 \\
\text { hours/day }\end{array}$ & $\begin{array}{l}\text { Conventional } \\
\text { Method Care }\end{array}$ & $\begin{array}{l}\text { Weight gain } \\
\text { and length of } \\
\text { hospitali- } \\
\text { zation. }\end{array}$ & 22.5 & 16.7 & $3 \cdot 9$ & $3 \cdot 3$ \\
\hline $\begin{array}{l}\text { Samra et } \\
\text { al., (2013) }\end{array}$ & $\begin{array}{l}\text { Faiyum, } \\
\text { Mesir }\end{array}$ & $\mathrm{RCT}$ & 22 & 18 & $\begin{array}{l}\text { LBW } \\
<2500 \text { g }\end{array}$ & $\begin{array}{l}\text { KMC for at } \\
\text { least } 3 \\
\text { hours/day }\end{array}$ & $\begin{array}{l}\text { Standard care } \\
\text { uses an } \\
\text { incubator. }\end{array}$ & Weight gain & 22.1 & 10.4 & 3.5 & 2.5 \\
\hline $\begin{array}{l}\text { Acharya } \\
\text { et al., } \\
\text { (2014) }\end{array}$ & Nepal & $\mathrm{RCT}$ & 63 & 63 & $\begin{array}{l}\text { LBW } \\
<2500 \text { g }\end{array}$ & $\begin{array}{l}\text { KMC for at } \\
\text { least } 6 \\
\text { hours/day }\end{array}$ & $\begin{array}{l}\text { Conventional } \\
\text { Method Care }\end{array}$ & Weight gain & 12.1 & 3.2 & 9 & 8 \\
\hline $\begin{array}{l}\text { Sharma et } \\
\text { al., (2016) }\end{array}$ & $\begin{array}{l}\text { Telangana, } \\
\text { India }\end{array}$ & $\mathrm{RCT}$ & 71 & 70 & $\begin{array}{l}\text { LBW } \\
<2500 \text { g }\end{array}$ & $\begin{array}{l}\text { KMC for at } \\
\text { least } 3 \\
\text { hours/day }\end{array}$ & $\begin{array}{l}\text { Intermediate } \\
\text { Intensive Care }\end{array}$ & Weight gain & 28.0 & 26.8 & $7 \cdot 3$ & 7.1 \\
\hline $\begin{array}{l}\text { Rahman } \\
\text { et al., } \\
\text { (2017) }\end{array}$ & $\begin{array}{l}\text { Dhaka, } \\
\text { Bangladesh }\end{array}$ & $\mathrm{RCT}$ & 40 & 40 & $\begin{array}{l}\text { LBW } \\
<2500 \text { g }\end{array}$ & $\begin{array}{l}\text { KMC for at } \\
\text { least } 8 \\
\text { hours/day }\end{array}$ & $\begin{array}{l}\text { Conventional } \\
\text { Method Care }\end{array}$ & Weight gain & 18.1 & 13 & $7 \cdot 7$ & 4.5 \\
\hline
\end{tabular}


Handayani et al./ Kangaroo Mother Care on Body Weight in Infants with Low Birth Weight

\begin{tabular}{|c|c|c|c|c|c|c|c|c|c|c|c|c|}
\hline \multirow{2}{*}{$\begin{array}{l}\text { Author } \\
\text { (Year) }\end{array}$} & \multirow{2}{*}{ Country } & \multirow{2}{*}{$\begin{array}{l}\text { Study } \\
\text { Design }\end{array}$} & \multicolumn{2}{|c|}{$\begin{array}{l}\text { Total of } \\
\text { Sample }\end{array}$} & \multirow{2}{*}{$\begin{array}{l}\text { Popula- } \\
\text { tion }\end{array}$} & \multirow{2}{*}{$\begin{array}{c}\text { Inter- } \\
\text { vention }\end{array}$} & \multirow{2}{*}{ Comparison } & \multirow{2}{*}{ Outcome } & \multicolumn{2}{|c|}{ Mean } & \multicolumn{2}{|c|}{ SD } \\
\hline & & & KMC & CMC & & & & & KMC & CMC & KMC & CMC \\
\hline $\begin{array}{l}\text { Rehman } \\
\text { et al., } \\
(2020)\end{array}$ & $\begin{array}{l}\text { Lahore, } \\
\text { Pakistan }\end{array}$ & $\mathrm{RCT}$ & 77 & 76 & $\begin{array}{l}\text { LBW } \\
<2500 \text { g }\end{array}$ & $\begin{array}{l}\text { KMC for at } \\
\text { least } 3 \\
\text { hours/day }\end{array}$ & $\begin{array}{l}\text { Conventional } \\
\text { Method Care }\end{array}$ & Weight gain & 10.2 & 7.9 & 1.6 & 1.7 \\
\hline $\begin{array}{l}\text { Azad et } \\
\text { al., } \\
(2020)\end{array}$ & $\begin{array}{l}\text { New Delhi, } \\
\text { India }\end{array}$ & RCT & 50 & 50 & $\begin{array}{l}\text { LBW } \\
<2500 \text { g }\end{array}$ & $\begin{array}{l}\text { KMC for at } \\
\text { least } 5 \\
\text { hours/day }\end{array}$ & $\begin{array}{l}\text { Conventional } \\
\text { Method Care }\end{array}$ & Weight gain & 11.0 & 9.8 & 7 & $5 \cdot 7$ \\
\hline $\begin{array}{l}\text { Jahan et } \\
\text { al., } \\
(2020)\end{array}$ & $\begin{array}{l}\text { Dhaka, } \\
\text { Bangladesh }\end{array}$ & RCT & 40 & 40 & $\begin{array}{l}\text { LBW } \\
<2500 \text { g }\end{array}$ & $\begin{array}{l}\text { KMC for at } \\
\text { least } 3 \\
\text { hours/day }\end{array}$ & $\begin{array}{l}\text { Conventional } \\
\text { Method Care }\end{array}$ & $\begin{array}{l}\text { Weight gain, } \\
\text { increase in } \\
\text { head circum- } \\
\text { ference and } \\
\text { body length }\end{array}$ & 18.3 & 13.5 & 7.8 & 4.8 \\
\hline
\end{tabular}


Handayani et al./ Kangaroo Mother Care on Body Weight in Infants with Low Birth Weight

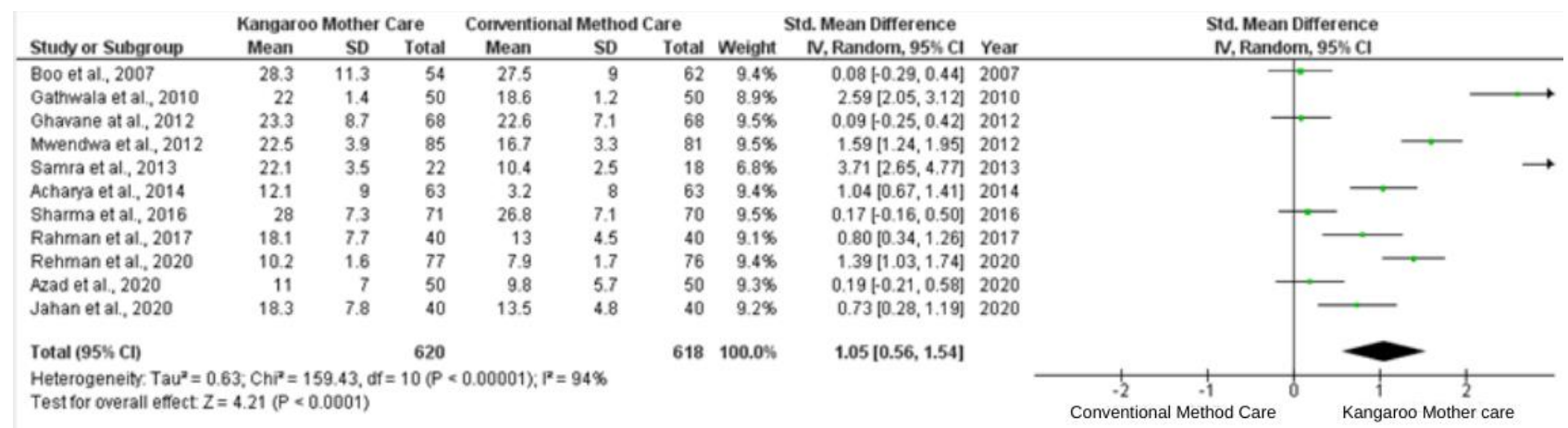

Figure 3. Forest plot The effect of kangaroo mother care on weight gain in infants with $L B W$

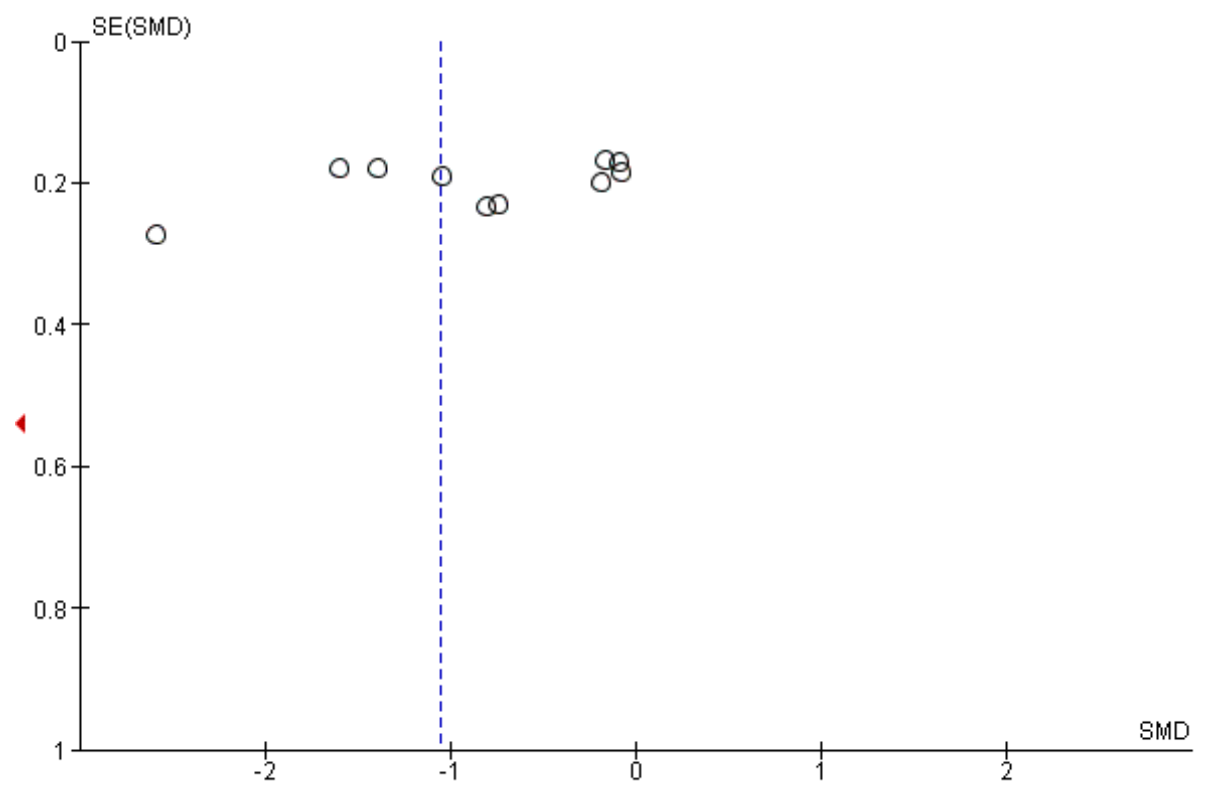

Figure 4. Funnel Plot Effect of kangaroo mother care on weight gain in infants with $L B W$

\section{DISCUSSION}

Systematic studies and meta-analyses raised the theme of the effect of kangaroo mother care on weight gain in LBW infants. This study discusses the KMC method which is considered important because it can be one of the treatments that can be carried out on LBW infants for temperature stabilization and weight gain.

Kangaroo Mother Care can increase body weight in LBW babies. This is in line with research (Conde and Díaz, 2016) kangaroo mother care (KMC) is the care of LBW babies by positioning the baby to make direct skin-to-skin contact with the mother or caregiver, this method is one method that can be done easily to improve health and well-being of LBW infants in the long term.

Several studies have shown the effect of the KMC method on increasing the weight of LBW babies, one of which is the research by Phirke \& Bantewad (2017) with the title "Evaluation of Kanga-roo Mother Care in Low Birth Weight Babies" with the number 
of research subjects being $80 \mathrm{BBL}$. The KMC method started after the mother was given counseling. Of the $40 \mathrm{BBL}$ born at $32-34$ weeks' gestation, the average birth weight was $1626 \mathrm{~kg}$. weight gain after KMC was seen in 40 of 57 infants after 4 days and all infants after 8-12 days, with a mean weight gain of 14.53 grams.

The ideal implementation of KMC can be carried out continuously, by performing the skin to skin contact (SSC) technique on an ongoing basis between the baby and the mother or caregiver. Research shows that KMC has a good effect on the baby and can be done easily by the mother or caregiver when compared to conventional care (Lawn et al., 2010).

The KMC method is no longer used when the baby doesn't want it anymore, this condition is usually in babies born at term and weighing $>2,500 \mathrm{~g}$. In these conditions, the baby generally starts to get restless or fussy when placed in the kangaroo position (Tshotetsi et al., 2019) .

Separate care for mother and baby using technology in the neonatal unit makes bonding difficult and creates barriers to breastfeeding. The KMC method was used to stimulate production (Anggraini \& Septira, 20-16). Several studies of the effect of KMC in breastfeeding show that breastfeeding takes longer, milk production is more stable, the number of breastfeeding per day increases, mother's confidence in breastfeeding increases.

Another study by Sharma et al., (2016) entitled "The effect of Kangaroo Mother Care in Comparison with Intermediate Intensive Care on the Growth Velocity in Preterm Infant with Birth Weight <2500 g: Randomized Controlled Trial". Randomly selected, the study showed a better and significant increase in body weight after KMC during hospitalization. The mean value is 24.21 with a standard deviation of 6.4 in the experimental group and in the control group the mean is $\mathbf{2 0 . 8 8}$ with a standard deviation of 5.1 .

KMC also has various advantages when compared to conventional methods of treatment, some of which are breastfeeding, increasing maternal trust, increasing emotional and affectionate bonds between mother and baby and can be done easily with very minimal costs (Tessier et al., 1998).

KMC can increase the weight of LBW babies because this intervention can make babies spend longer with their mothers so that breastfeeding becomes longer, milk production becomes more stable, the number of breastfeeding per day will increase so that it can indirectly increase nutritional intake in infants and will affect weight gain (Samra et al., 2013).

Weight gain can also be influenced by the stability of the baby's body temperature, KMC can provide warmth to the baby, this can improve the quality of the baby's sleep so that the baby will sleep calmly and will increase the suction reflex which affects the intake or nutritional intake of the baby so that the baby's nutritional intake increases. weight gain in LBW infants becomes faster (Alisjahbana et al., 2017). By using the KMC method, the stable temperature of LBW babies can be maintained because in this method the baby is placed attached to the mother's stomach which functions as a thermo-regulator. Another mechanism that occurs is skin-to-skin contact between mother and baby can increase the hormone cortisol in the baby which has an impact on the baby's sleep quality increases.

According to Ramanathan et al., (2001) weight gain in LBW infants can also be influenced by the balance between food intake and energy expenditure, because during the KMC method the baby will expend less energy. In addition, the success of the KMC method is also influenced by 
knowledge, education, mother's attitude, and family support as well as health facilities and services provided. Mother's knowledge is influenced by mother's education where the higher a person's education level, the higher knowledge about something, as well as mother's knowledge about KMC. Good knowledge will certainly affect the mother's attitude (Agussafutri et al., 2021).

\section{AUTHOR CONTRIBUTION}

Anggun Fitri Handayani is the main researcher who selects the topic, searches for and collects research data. Yulia Lanti Retno Dewi and Eti Poncorini Pamungkasari analyze data and review research documents.

\section{FUNDING AND SPONSORSHIP}

This study is self-funded.

\section{CONFLICT OF INTEREST}

There is no conflict of interest in this study.

\section{ACKNOWLEDGMENT}

We thank the database providers Google Scholar, Pubmed, Science Direct, and Springerlink.

\section{REFERENCE}

Agussafutri WD, Pangesti CB, Wijayanti FA (2021). Pengaruh demonstrasi kangaroo mother care (KMC) terhadap perubahan tingkat pengetahuan dan sikap ibu dalam melaksanakan kmc untuk mengurangi demam di pmb elisabeth (the effect of the kangaroo mother care (KMC) demonstration on changes in mothers' knowledge and attitudes in implementing KMC to reduce fever at PMB elisabeth). J Ners Kebidanan Indones. 12(2): 1-8. https://doi.org/10.36419/JKI.V12I2.490

Alisjahbana A, Usman A, Lrawaty S, Triyati A (2017). Prevention of hypothermia of low birth infants using the kangaroo method. Paediatr. Indones. 38(9-10): 205-214. https://doi.org/10.14238/PI38.9-10.1998.205-14.

Anggraini DI, Septira S (2016). Nutrisi bagi bayi berat badan lahir rendah (BBLR) untuk mengoptimalkan tumbuh kembang (nutrition for low birth weight (LBW) babies to optimize growth). Jurnal Majority. 5(3): 151-155. Retrieved from: http://juke.kedokteran.unila.ac.id/index.php/majority/article/view/1053.

CEBM (2021). Critical appraisal tools Center for Evidence-Based-Medicine. Retrieved from https://www.cebm.ox.ac.uk/resources/ebmtools/criticalappraisal -tools.

Cha S (2017). Print. https://doi.org/10.108o/16549716.2017.1267961.

Conde AA, Díaz RJL (2016). Kangaroo mother care to reduce morbidity and mortality in low birthweight infants. Cochrane Database of Systematic Reviews, 2016(8). https://doi.org/10.1002/14651858.CDoo2771.PUB4/MEDIA/CDS R/CDoo2771/IMAGE_N/NCDoo2771CMP-002-17.PNG.

Hasegawa J, Arakawa K, Nakamura M, Matsuoka R, Ichizuka K, Katsufumi O, Sekizawa A, Okai T (2011). Analysis of placental weight centiles is useful to estimate cause of fetal growth restriction. $\mathrm{J}$ Obstet Gynaecol. 37(11): 1658-1665. https://doi.org/10.1111/J.1447-0756.2011.01600.X.

Lawn JE, Mwansa KJ, Horta BL, Barros FC, Cousens S (2010). Kangaroo mother care to prevent neonatal deaths due to preterm birth complications. Int. J. Epidemiol. 39(1): i144-i154. https://doi.org/10.1093/IJE/DYQ03.

Phirke, DS, Bantewad S (2017). Evaluation of Kangaroo Mother Care in Low Birth 
Weight Babies. JMSCR. DOI: https://doi.org/10.18535/jmscr/v5i9.02

Punia D (2020). Literatur review asuhan kebidanan pada bayi BBLR (berat badan lahir rendah) dengan ikterus neonatorum patologis (literature review of midwifery care in low birth weight babies with pathological neonatal jaundice).

Ramanathan K, Paul VK, Deorari AK, Taneja U, George G (2001). Kangaroo mother care in very low birth weight infants. Indians J. Pediatr. 68(11): 1019-1023. https://doi.org/10.1007/BFo2722345.

Rohani S, Wahyuni R (2017). Faktor-faktor yang berhubungan dengan kejadian ikterus pada neonatus (factors associated with the occurrence of jaundice in neonates). Jurnal Aisyah: Jurnal Ilmu Kesehatan. 2(1): 75-80. https://doi.org/10.30604/jika.v2i1.35.

Samra NM, Taweel AE, Cadwell K (2013). Effect of intermittent kangaroo mother care on weight gain of low birth weight neonates with delayed weight gain. $\mathrm{J}$
Perinat Educ. 22(4): 194-200. https://doi.org/10.1891/1058-1243.22.4.194. Sharma D, Murki S, Pratap OT (2016). The effect of kangaroo ward care in comparison with intermediate intensive care on the growth velocity in preterm infant with birth weight. Eur. J. Pediatr. 175(10): 1317-1324. https://doi.org/10.1007/So0431016276Y.

Tessier R, Cristo M, Velez S, Girón, Calume SFD, Ruiz PJG, Charpak Y, Charpak N (1998). Kangaroo mother care and the bonding hypothesis. Pediatrics. 102(2): e17-e17. https://doi.org/10.1542/PEDS.102.2.E17.

Tshotetsi L, Dzikiti L, Hajison P, Feresu S (2019). Maternal factors contributing to low birth weight deliveries in Tshwane District, South Africa. PLOS ONE. 14(3): eo213058. https://doi.org/10.1371/JOURNAL.PONE.0213058.

WHO (2014b). Low Birth Weight Policy Brief. South Asia, 28(4): 7. Retrieved from https://ijhd.upnvj.ac.id/index.php/ijhd/article/view/39/38 on October 12, 2021. 